\title{
Vietnamese and the NP/DP parameter
}

\author{
Trang Phan and Eric T. Lander \\ Ghent University/University of Hai Duong and Ghent University
}

\section{Introduction}

This paper investigates the place of Vietnamese in the binary NP/DP typology as formulated by Bošković $(2005,2008,2009,2010)$. According to him there are a number of properties that set apart languages without an overt definite determiner (NP languages), e.g. SerboCroatian, Warlpiri, and Japanese, from languages with a definite determiner (DP languages), e.g. English, French, and Lakhota. Here and below we follow Bošković in taking DP to be the functional projection hosting definite determiners (and not, for instance, indefinite determiners).

(1) SOME NP vs. DP PRoperties (BoŠKović 2005, 2008, 2009, 2010) ${ }^{1}$

\begin{tabular}{|l|l|l|}
\hline Properties & NP & DP \\
\hline a. Definite determiner & - & + \\
\hline b. Left branch extraction & $+/-$ & - \\
\hline c. Radical pro-drop & + & - \\
\hline d. Obligatory number morphology & $+/-$ & + \\
\hline e. TP & - & + \\
\hline f. Subject expletives & - & + \\
\hline g. Subject-object asymmetry & - & + \\
\hline h. Negative raising & - & + \\
\hline i. Focus adjacency & - & $+/-$ \\
\hline j. Focus morphology on negative constituents & + & $+/-$ \\
\hline
\end{tabular}

At first glance, Vietnamese ${ }^{2}$ fits in with the NP languages. As a simple illustration of this, consider two important contexts in which definite articles normally appear in DP languages (as discussed by Himmelmann 2001). While a language like English shows an overt definite article in these contexts $(2 \mathrm{a}, 3 \mathrm{a})$, Vietnamese does not (2b, 3b), suggesting that the latter is an NP language.

We are grateful to Liliane Haegeman, Nigel Duffield, Jaehoon Choi, Andrew Weir, and two anonymous reviewers for comments. Trang Phan's research is funded by FWO project 2009-Odysseus-Haegeman-G091409. Eric Lander's research is funded by BOF grant 01D30311, awarded by UGent.

Abbreviations: ANT: anterior. ASR: assertion. ASP: aspect. CLS: classifier. COMP: complementizer. FOC:

focus. FUT: future. GEN: genitive. NEG: negation. PL: plural. PROG: progressive. PRT: particle. SG: singular.

${ }^{1}$ This is not a complete list of the properties mentioned by Bošković. The properties which are not brought up in this paper are either irrelevant to Vietnamese or are open to future research.

${ }^{2}$ Vietnamese noun phrases in general consist of the head $\mathrm{N}$ and the following elements: a pre-nominal numeral, a pre-nominal classifier and one or more post-nominal modifiers. These elements are arranged in a fixed order (Num CLS N Adj Dem), as seen in (i).
(i) ba con mèo đen ấy
three CLS cat black Dem
'those three black cats'

See Emeneau (1951), Thompson (1965), Nguyen (2004) for a description of Vietnamese noun phrases. 
(2) Larger situational use = "first mention of entities that are considered to be unique, and hence generally identifiable in a given speech community" (Himmelmann 2001: 833)
a. the sun
the Queen
b. Ø Mặt trời
Ø Nữ hoàng

(3) Associative-anaphoric use = "the first mention of an entity that is not unique per se but with respect to a previously mentioned referent" (Himmelmann 2001: 833)

a. The man drove past our house in a car. The exhaust fumes were terrible.
b. Người đàn ông lái xe qua nhà chúng tôi. Ø Mùi khói thật kinh khủng CLS man drive carpass house our fume real terrible 'The man drove a car past our house. The fumes were terrible.'

However, we will show that the status of Vietnamese within Bošković's NP/DP parameter is not so straightforward. In fact, Vietnamese displays both NP and DP properties, raising doubts about the status of the NP/DP macro-parameter. The dual status of Vietnamese suggests that the NP/DP typology needs to be refined. In fact, the way the properties in (1) pattern in Vietnamese reveals that there are multiple smaller parameters at stake, not just the presence or absence of DP. Also important is the fact that Vietnamese is a topic-prominent language.

Here we adopt Paul and Whitman's (2015) notion of topic-prominence. According to them, topic-prominent languages never fill their $\operatorname{Top}^{0}$ heads by movement, but by the basegeneration of topic particles. ${ }^{3}$ Vietnamese, with its topic particle thi ${ }^{4}$ is a topic-prominent language in this sense, and much of its clausal syntax is overtly arranged according to topicality, but not according to focus or other quantificational elements.

In this paper we will focus mostly on the properties listed in (1). Properties (a-g) are discussed in section 2. In section 3 we discuss properties (h-j). Here we observe that negation, focus, and wh-words (i.e. quantificational elements; Starke 2001) do not move, whereas in DP languages they typically do. Section 4 concludes the paper.

\section{The dual status of Vietnamese}

In this section we examine the NP/DP properties (a-g) in Vietnamese.

\subsection{Absence of lexically inherent definite determiners}

The most crucial of Bošković's generalizations is that DP languages have definite determiners, while NP languages lack them. In this section we show that, though there are a

\footnotetext{
${ }^{3}$ Paul and Whitman's (2015) notion of topic-prominence is sufficient for the sake of the current paper. In upcoming work (Phan and Lander, in prep.) we suggest that topicality is a function of specificity (along the lines of Cresti 1995, Portner 2002), meaning that topic particles are only part of a bigger set of specificity markers which include plural markers, the expletive subject, classifiers, etc.

${ }^{4}$ In addition to the canonical topic particle thi, it has been argued in the literature that Vietnamese also employs other overt topic markers such as là (Cao 2004) and mà (Duffield, in prep).
} 
number of ways to express definiteness in Vietnamese, none are consistent enough to count as a fully grammaticalized means of definiteness marking. That is, Vietnamese lacks genuine definite determiners. ${ }^{5}$

Nguyen (2004) claims that Vietnamese displays a paradigm of lexical determiners, namely those in (4).

(4) Candidates for D in Vietnamese (Nguyen 2004)
a. một 'one' [-Plural, -Definite]
b. những [+Plural, - Definite $]$
c. các [+Plural, + Definite $]$

There are reasons to challenge Nguyen's (2004) conclusion. We will argue that the items in (4) have important properties which differentiate them from genuine, fully grammaticalized definite determiners (D). First, they are not obligatory:
a. Con rất ngoan
child very well-behaved
'The child/children is/are very well-behaved.'

b. Các con rất ngoan

CAC child very well-behaved

'The children are very well-behaved.'

(5) shows that the presence of các only forces the plural reading, but not necessarily the definite reading, because the noun con 'child' can be interpreted as definite either with or without các. ${ }^{6}$

Second, contra Nguyen's (2004) description, there is no inherent contrast between nhũng [Definite] and các [+Definite]. In fact, it is easy to find minimal pairs in which the presence of nhũng or các does not result in a difference in terms of definiteness, as seen in (6) and (7). The definiteness of the nominal phrases in (6) is already guaranteed by the possessor cuia tô $i$ 'of mine' or the demonstrative $\hat{a} y$ 'that', meaning that nhĩng and các are purely plural markers in these cases. ${ }^{7}$
a. Những
sinh viên
của tôi
rất chăm chỉ
NHUNG
student of me
very hard-working

\footnotetext{
${ }^{5}$ As one reviewer notes, the presence of definite determiners may indicate DP status, but the absence of definite determiners does not always mean NP status (for instance, certain Slavic languages are still DP languages despite their lack of determiners). However, as another reviewer points out, Vietnamese constitutes an especially interesting dataset since its definite-like markers seem to be optional, setting it apart from both languages with obligatory definite determiners and languages with no definite determiners.

${ }^{6}$ The optionality of nhĩng and các in representing definiteness is further reinforced in anaphoric (strong definite) contexts:

(ii) Giáo-sư và sinh viên đều đến dự tiệc. Sinh-viên thì say bí-tỉ. Professor and student both come attend party. Student TOP drunk DEG 'Professors and students came to the party. The students are very drunk.'

In the second occurrence, the bare form sinh-viên 'student' in the absence of nhũng and các is sufficient to obtain the definite interpretation. We thank a reviewer for this suggestion.

${ }^{7}$ See also Emeneau (1951) and Kirby (2006) for similar claims.
} 
'My students are very hard-working.'

b. Các sinh viên của tôi rất chăm chỉ

CAC student of me very hard-working

'My students are very hard-working.'

(Bui 2000: 22)
a. Những sinh viên ấy rất chăm chỉ
NHUNG student that very hard-working
'Those students are very hard-working.'
b. Các sinh viên ấy rất chăm chỉ
CAC student that very hard-workinng
'Those students are very hard-working.'

That is to say, nhüng and các can only designate definiteness for a noun phrase whose definiteness value is underspecified.

Third, another piece of evidence to indicate that nhüng and các are not genuine determiners comes from their distribution. Nhüng and các are strictly incompatible with numerals, which suggests that they might occupy the same position as numerals. ${ }^{8}$
a. *Những ba sinh viên
NHUNG three student
'the three students'
b. *Các ba sinh viên
CAC three student
'the three students'

As can be seen from the English translations, there is no such incompatibility of the determiner the and the numeral three in English.

Although Vietnamese displays lexical items that may serve to contribute to the expression of definiteness, these are not determiners in the technical sense. ${ }^{10}$ According to this diagnostic, then, Vietnamese should be classified with the NP languages.

\subsection{Left-branch extraction}

According to Bošković (2005, 2010), DP languages disallow left-branch extraction (LBE) but may allow complement extraction (CE), while NP languages may allow LBE but disallow CE. This can be illustrated for English (DP) in (9) vs. Serbo-Croatian (NP) in (10).

\footnotetext{
${ }^{8}$ Note that these elements appear to be at least partially responsible for number marking. While number should of course be kept distinct from numerals, the two are closely related, especially from the perspective of grammaticalization and historical change.

9 The only possible interpretation of (8a) is 'abundantly three students' or 'as many as three students'.

${ }^{10}$ If the Vietnamese plural markers are not directly linked to definiteness, the question arises what really motivates their presence in Vietnamese nominal phrases. Based on a close examination of their distributional and interpretational properties, Phan \& Lander (in prep.) argue that nhũng and các are markers of partitive specificity (in the sense of Enç 1991, Farkas 2002), and that the definite-like phenomena and optionality of nhũng and các are manifestations of their specificity.
} 
b. [Of whom] $]_{i}$ do government employees see [pictures_i] everyday? $\quad \mathcal{C E}$

(Bošković 2010:20)

(10) a. Lijepe i $_{\text {je video [_i kuce] }}$

$\checkmark \mathrm{LBE}$

beautiful is seen houses

'Beautiful houses, he saw.'

(Bošković 2005:2)

b. *Koga si pronasla knjigu

${ }^{*} \mathrm{CE}$

who.GEN are found book

Intended: 'Of whom did you find the book?'

(Bošković 2010:15)

Bošković's explanation for this difference between English and Serbo-Croatian involves three ingredients. First he appeals to Chomsky's (2000) Phase Impenetrability Condition ${ }^{11}$ (PIC), which requires materials in a phase complement to move to the phase edge in order to be accessible for the rest of the derivation. Second, Bošković appeals to anti-locality (Abels 2003), the idea that movement cannot be too short, meaning that a moved element must pass a full phrase, not just a segment. Third, he assumes that adjective phrases are adjoined to NP. ${ }^{12}$

According to Bošković's NP/DP theory, English projects a DP, which is considered a phase. In order to derive LBE in English, the adjective beautiful in (9a)/(11a) would first have to move to the edge of DP, Spec-DP, by the PIC. From there it would move on to Spec-CP to get a focused interpretation. However, the first movement to Spec-DP violates anti-locality, ruling out LBE. The movement of the complement of whom in $(9 \mathrm{~b}) /(11 \mathrm{~b})$, however, does not violate anti-locality, and thus CE is derivable in English.

(11) English

a. *LBE: anti-locality or PIC violated

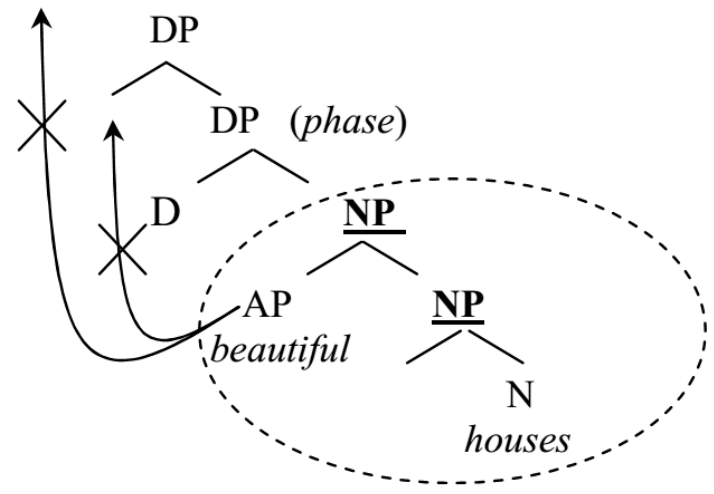

b. CE: no anti-locality violated

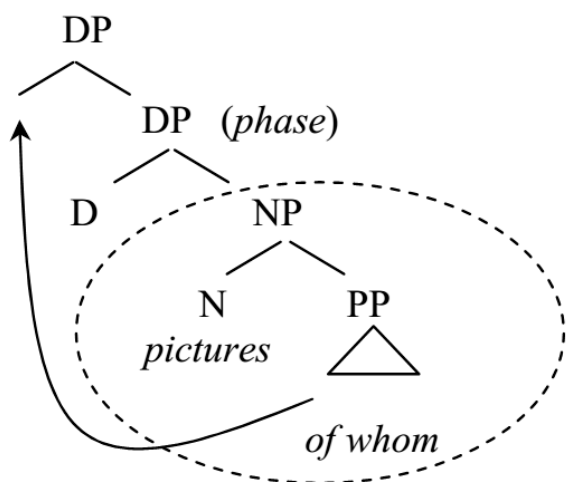

(adapted from Li 2012:61)

\footnotetext{
${ }^{11}$ As noted by one of the reviewers, the phase-based analysis is in fact only one of the two analyses Bošković (2005) offers in order to account for these facts.

${ }^{12}$ For Bošković the main point is that NP languages do not have the functional projection DP. Other functional projections such as dedicated projections for different kinds of adjectives $(\alpha \mathrm{Ps})$, for instance, may very well exist in NP languages. For his phase-based approach, however, it is crucial that adjectives are at the phase edge, which for NP languages means NP. Unless $\alpha$ Ps can also be stipulated to serve as phases, this means that adjectives must be adjoined to NP.
} 
In Serbo-Croatian, on the other hand, there are no overt determiners, so DP is not projected. Thus NP is a phase instead. LBE is possible in this language because the adjective lijepe in $(10 a) /(12 a)$ is already at the phase edge, enabling it to move further up to Spec-CP. However, $\mathrm{CE}$ is not possible because the complement koga in $(10 \mathrm{~b}) /(12 \mathrm{~b})$ must first move to the phase edge, Spec-NP, a movement which is too short.

\section{(12) Serbo-Croatian}

a. LBE: AP is at phase edge already

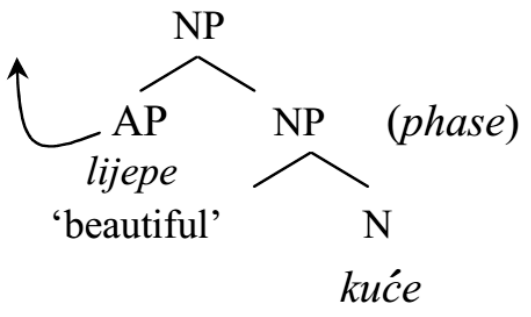

'houses' b. CE: anti-locality and PIC violated

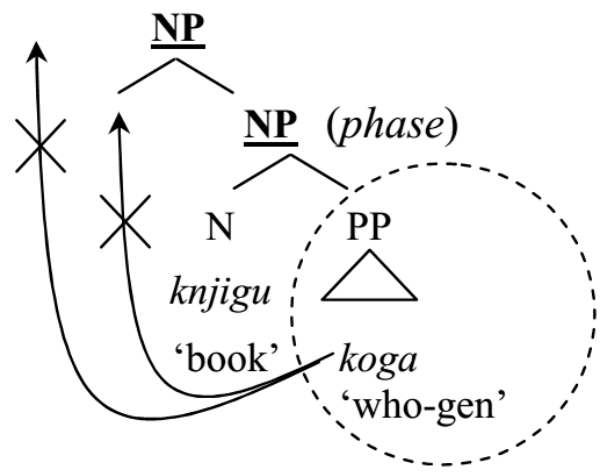

(adapted from Li 2012:62)

The crucial idea in this account, then, is whether or not movement to the phase edge is possible. In English, movement to the phase edge is impossible in the case of adjunct extraction, but possible in the case of complement extraction. In Serbo-Croatian, there is no movement to the phase edge in the case of adjective extraction (because the adjective is already at the phase edge), but movement to the phase edge is too short in the case of complement extraction.

Turning now to Vietnamese, we observe that CE like $(9 b) /(11 b)$ is quite obviously banned in this language due to its $w h$-in-situ character.
a. Của ai anh thấy ảnh hàng ngày?
of who 2SG saw picture everyday
'Of whom did you see a picture everyday?'
b. Anh thấy ảnh của ai hàng ngày? ${ }^{13}$
2SG see picture of who everyday
'Of whom did you see a picture everyday?'

As for LBE, the exact counterpart of the Serbo-Croatian example in $(10 a) /(12 a)$ is ungrammatical, as seen in (14).
(14) * Đẹp
anh đã thấy những
ngôi nhà
beautiful 3SG ANT see PL
CLS house
Intended: 'Beautiful houses, he saw.'

\footnotetext{
${ }^{13}$ Note that the generalization here about LBE and CE is not about LF movement, but rather about which movements are overtly realized in narrow syntax. See Tsai (2009: ch.3) for evidence that Vietnamese $w h$-in-situ does not involve LF movement.
} 
The only construction that superficially looks like a case of LBE is in listing contexts, as illustrated in (15).

(15) Context: At a racetrack, A has asked how many cars of which colors B had seen. B answers:

(Màu) đỏ tôi thấy ba cái, (màu) vàng tôi thấy hai cái color red I see three CLS, color yellow I see two CLS

'As for (the color) red, I saw three (cars); as for (the color) yellow, I saw two.'

Since we observe island effects in (16), it is reasonable to assume movement of (màu) đỏ '(the color) red', as opposed to an analysis in which (màu) đỏ is a base-generated topic. ${ }^{14}$
a. * [(Màu) đỏ $]_{i}$ tôi rời đi Adjunct [sau khi color red I leave away after
mua ba cái $\left.t_{\mathrm{i}}\right]$ Intended: 'Red I left after buying three (cars).'
buy three CLS color red I meet CLS man buy three CLS Intended: 'Red I met the man who bought three.'
b. * [(Màu) đỏ $]_{\mathrm{i}}$ tôi gặp ComplexNP[người đàn ông mua ba cái $\left.t_{\mathrm{i}}\right]$

Taking a closer look, the Vietnamese example actually patterns with English raised contrastive topics. ${ }^{15}$

(17) Q: How about French films? Did you see any French films at the festival?

A: French $\mathrm{i}_{\mathrm{i}}$ didn't see any $t_{\mathrm{i}}$ films, but German $\mathrm{I}_{\mathrm{j}}$ did see some $t_{\mathrm{j}}$ films ${ }^{16}$.

Q: Phim Pháp thì sao?
film French TOP how?
Mày có xem bộ phim Pháp nào ở lễ hội không?
2SG ASR see CLS film French any at festival NEG
'How about French films? Did you see any French films at the festival?'
A: Pháp thì tao không xem phim nào, French TOP 1SG NEG see film any nhưng Đức thì tao có xem vài phim. but German TOP 1SG ASR see some film 'French I didn't see any films, but German I did see some films.'

If we are on the right track analyzing (15) as a raised contrastive topic instead of as LBE, then we would expect that other phrases can also occur in such a construction as long as they can be interpreted as contrastive topics. The prediction is borne out, as shown in (19).

(19) Q: Xe của tao thì sao? Mày có thấy cái xe nào của tao không? car of 1SG TOP how? 2SG ASR see CLS car any of 1SG NEG 'How about my cars? Did you see any car of mine?'

\footnotetext{
${ }^{14}$ Thanks to Guglielmo Cinque for discussion of these examples.

${ }^{15}$ Thanks to Andrew Weir for discussion.

${ }^{16}(17 \mathrm{~A})$ is not perfect for all English speakers. The grammaticality of (17A) is based on judgments from Andrew Weir and Eric Lander.
} 


A: Của mày thì tao không thấy cái nào,
of 2SG TOP 1SG NEG see CLS any,
nhưng của cái Lan thì tao có thây hai cái.
but of CLS Lan TOP 1SG ASR see two CLS
'Of yours, I didn't see any, but of Lan, I saw two.'

Therefore, the ungrammatical status of (14) is due to the fact that dep 'beautiful' cannot be interpreted as a contrastive topic. In other words, Vietnamese lacks LBE, but it patterns with English in having a raised contrastive topic construction.

Note, importantly, that Bošković $(2005,2010)$ does not require NP languages to necessarily display LBE in order to qualify for NP status. It is only the case that DP languages cannot have LBE; NP languages may or may not have LBE. In other words, the LBE generalization is a one-way generalization. Thus there is at least a threeway split between languages: NP languages with LBE, NP languages without LBE, and DP languages (without LBE). Since Vietnamese does not have LBE, it could be either NP or DP by this diagnostic.

\subsection{Radical pro-drop and non-obligatory number morphology}

Bošković (2010) claims that radical pro-drop is possible only in NP languages. By radical pro-drop, he means productive discourse-based subject-/object-drop in the absence of rich verbal argeement. This is distinct from the type of agreement-licensed argument drop found in languages like Italian and Spanish. ${ }^{17}$

Vietnamese appears to be a radical pro-drop language (in the sense of Roberts and Holmberg 2010). The general properties of radical pro-drop languages include the following:

i. Possibility of having null definite subjects

ii. Possibility of dropping the object in addition to the subject

iii. Lack of verbal agreement

iv. Possibility of having a null generic subject

v. Licensing of anaphoric null subjects is not restricted by structural conditions (e.g. ccommanding antecedents).

Vietnamese displays all these properties. The first three properties are exemplified in (20):
a. Mary thích Tom.
Và $\varnothing$ cũng thích Peter.
Subject-drop
Mary like Tom and $\varnothing$ also like Peter
'Mary likes Tom. And she $_{i}$ also likes Peter.'
b. Mary thích Tom. Nhưng Peter không thích Ø.
Mary like Tom but Peter NEG like $\varnothing$
Object-drop
'Mary likes Tomi. But Peter does not like himi.'

In (20), both the definite subject (20a) and object (20b) can be dropped, as long as their antecedents can be recovered from the context. Moreover, it is easily observed that the verb stays bare, with no person or number inflection.

\footnotetext{
${ }^{17}$ See Lander and Haegeman (2014) for other types of pro-drop which are also discourse-based and nonagreement based, but which still do not qualify as radical pro-drop in Bošković's strict sense.
} 
Vietnamese also allows for generic null subjects. In particular, the Vietnamese counterpart of the English generic pronoun one can be null:
Ø không được hút
thuốc
ở đây
$\varnothing$ NEG can smoke
'One can't smoke here.'
cigarette in here

Finally, c-commanding antecedents are not required to license null subjects (as long as the antecedent is the topic). See example (22) (adapted from Holmberg 2010:92).

(22) Nam đã nói gì đâu,

Nam ANT say thing NEG

mà Hòa nói là $\varnothing$ muốn mua một cái xe mới

but Hòa say COMP $\varnothing$ want buy one CLS car new

'Nam 1 hasn't said anything, but Hòa ${ }_{2}$ says he ${ }_{1 / 2}$ wants to buy a new car.'

Since pro-drop in Vietnamese is topic-driven, it qualifies as radical pro-drop. By this diagnostic, Vietnamese is an NP language.

Related to the property of radical pro-drop is the fact that Vietnamese lacks number morphology (or is 'number neutral' in some terminologies). According to Bošković (2010: 10), "Number morphology may not be obligatory only in NP languages". Indeed, in Vietnamese some nouns can be interpreted as plural without the plural markers các or nhũng.

(23) Công nhân nước tư bản làm việc rất đúng giờ. worker country capitalist work very right time

'Workers of capitalist countries are very punctual at the workplace.'

The idea behind the connection between radical pro-drop and non-obligatory number morphology starts with the requirement that number feature on D be realized overtly. In DP languages this means that the number feature is realized on the verb instead, leading to the correlation in DP languages between rich verbal morphology and pro-drop. For NP languages this number requirement does not hold in the first place, since they lack D altogether. Accordingly NP languages may or may not have number morphology. See Bošković (2010: 21-22). Whether or not we accept the details of Bošković's proposal for the connection between radical pro-drop and non-obligatory number morphology, Vietnamese patterns with NP languages on both counts.

\subsection{Presence of TP}

Taking one version of the nominal/clausal parallelism hypothesis (i.e. $[\mathrm{C}[\mathrm{T}[\mathrm{V}]]]=[\mathrm{P}[\mathrm{D}$ $[\mathrm{N}]]$ ) seriously, Bošković (2010) posits that NP languages lack TP. We will argue that this generalization simply does not extend to Vietnamese.

In addition to contextual and adverbial elements, Vietnamese employs a number of free preverbal functional morphemes ${ }^{18}$ which are generally considered to add a certain

\footnotetext{
${ }^{18}$ Bošković also makes a special note that Japanese and Turkish have overt temporal morphology, but they can still be considered to lack $\mathrm{T}$ because the temporal morphemes are in fact only part of the morphologically complex verb: "A mere presence of temporal verbal morphology does not necessarily require positing a dedicated TP projection” (Bošković 2010: 26). As studied by Phan (2013), the markers discussed here are not
} 
temporal/aspectual value to the verb with which they occur: the future $s \tilde{e}$, the anterior $\approx \tilde{a}$ and the progressive đang (see Trinh 2005; Duffield 2007, 2013; Phan 2013). As argued by Duffield (2013) and Phan (2013), the future sẽ is base-generated in T, whereas đã and đang, though essentially aspectual, also bear a tense feature. One straightforward piece of evidence for these claims comes from the fact that when these elements occur to the left of negation, they are obligatorily interpreted as tense markers (in the absence of negation they are ambiguous between temporal and aspectual readings):
a. Tôi đã không đi New York 1SG ANT NEG go New York 'I didn't go to New York.'
b. Tôi đang không đi New York 1SG PROG NEG go New York 'I am not going to New York.'

As discussed at great length in Duffield (2013), Phan (2013), the markers are rigidly ordered as follows:

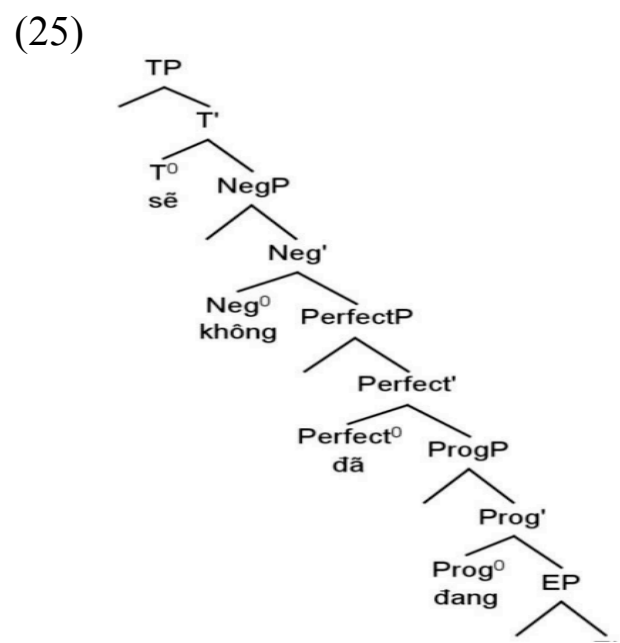

(Phan 2013: 155)

Given the hierarchy above, (24) shows cases of head movement, where the anterior marker (24a) and the progressive marker (24b) have moved to $\mathrm{T}$, to the left of negation. We refer to Duffield (2013) and Phan (2013) for more details, but suffice it to say that TP is present in Vietnamese as an independent functional projection.

Since TP is present, then, some TP-related effects are expected in Vietnamese. This is exactly what we find (see section 2.6).

\subsection{Subject expletive}

Related to the alleged generalization that NP languages lack TP, Bošković (2010) proposes that NP languages should also lack subject expletives, which canonically occupy Spec-TP.

bound affixes on the Vietnamese verb but are independent morphemes with distinct interpretational and distributional properties. 
It has been observed in the literature (Nguyen and Nguyen 2011, Dao 2012) that in colloquial Vietnamese ${ }^{19}$ the third person singular prounoun $n o$ 'it' can naturally act as a non-referential expletive subject in all expected environments: either as a there- or $i t$-expletive: ${ }^{20}$

(26) a. there-expletive

Trên bàn (nó) không có cái bút nào on table NÓ NEG exist CLS pen any

'There isn't any pen on the table.'

b. it-expletive

(Nó) mưa bây giờ đấy

NÓ rain now PRT

'It is about to rain now.'

There is also crosslinguistic evidence for the unexpected presence of expletive-like elements in null subject languages, most notably in Finnish (Holmberg and Nikanne 2002) and in nonstandard varieties of European Portuguese (Carrilho 2007). It is often claimed that expletives in these languages are actually not expletive subjects as in English. In particular, Finnish sita "is not an expletive subject but an expletive topic" (Holmberg \& Nikanne 2002:96), while in Portuguese "a projection headed by Force must be present and that the expletive occupies its Spec position.” (Carrilho 2007:12)

However, Vietnamese nó does not appear that high in the structure: it occupies neither the Spec-Top(ic)P nor the Spec-ForceP position. First, nó must follow the topic marker thi.
a. Trên bàn thì (nó) không có cái bút nào on table TOP NÓ NEG exist CLS pen any
'On the table, there isn't any pen.'
b. Hôm nay thì (nó) mưa
today TOP NÓ rain
'Today, it rains.'

If we place nó before the topic marker (cf. Finnish), the result is ungrammatical:

(28) a. Trên bàn (*nó) thì không có cái bút nào on table NÓ TOP NEG exist CLS pen any

'On the table, there isn' any pen.'
b. Hôm nay (*nó) thì mưa
today NÓ TOP rain
'Today, it rains.'

If we try placing nó before the Spec-TopP position (cf. Portuguese), the resulting sentence is also out.

(29) a. (*Nó) trên bàn thì không có cái bút nào NÓ on table TOP NEG exist CLS pen any

\footnotetext{
${ }^{19}$ Note that the expletive pronoun is used very often in spoken language, but not in formal written Vietnamese.

${ }^{20}$ For diagnostics to distinguish between the referential nó and the expletive nó in Vietnamese, see Greco, Phan and Haegeman (in prep.).
} 
'On the table, there isn't any pen.'

b. (*Nó) hôm nay thì mưa

NÓ today TOP rain

'Today, it rains.'

These examples indicate that unlike Finnish sita and Portuguese ele, Vietnamese nó cannot be higher than either Top ${ }^{0}$ or Spec-TopP. Therefore it is reasonable to think that nó stays in the subject domain.

Since Vietnamese nó is optional (in contrast with the English expletive), we might wonder what the contribution of nó is to the sentence. Its contribution can be teased out in existential sentences, where the presence of nó turns a generic statement into a statement about a specific event:

(30) a. Không có ma NEG exist ghost

'Ghosts don't exist.'

b. Nó không có ma

NÓ NEG exist ghost

'Speaking of some place/time, there is no ghost there/at that time.'

The presence of nó thus seems to activate a functional layer whose role is to relate predicative structure to a specific context.

Here, then, we have another DP(-like) property in Vietnamese. Interestingly, the expletive may be connected more to the topic-prominent nature of Vietnamese than to the existence of TP in this language. To the extent that both topic particles and nó can be said to be markers of (certain kinds of) specificity, the expletive in Vietnamese can be related to the language's topic-prominent nature, rather than the fulfillment of a formal Spec-TP-filling role.

\subsection{Subject-object asymmetries}

Again related to Bošković's (2010) generalization about TP is the claim that NP languages should not display subject-object asymmetries. In a DP language like English, for instance, extraction out of objects is allowed, but extraction out of subjects is not. ${ }^{21}$

(31) a. ${ }^{*} \mathrm{Who}_{\mathrm{i}}$ did friends of $t_{\mathrm{i}}$ see you?

b. Who did you see friends of $t_{\mathrm{i}}$ ?

Vietnamese seems to display a difference in topicalization between subjects and objects. In (32) we see that part of the object may be topicalized with two different interpretations arising. In (33), however, we see that part of the subject cannot be topicalized as easily, since only the topic-in-situ interpretation is grammatical and not the raised topic interpretation. In the raised topic interpretation, the topic modifies only 'the two books' and can be

\footnotetext{
${ }^{21}$ Crucially, the asymmetry here is indeed a test for movement to Spec-TP, because extraction is only impossible for subjects which move to Spec-TP. For instance, in Spanish, extraction is allowed only out of postverbal subjects, which do not move to Spec-TP, but we cannot extract out of preverbal subjects which do move to Spec-TP (see Gallego and Uriagereka 2007, cited in Bošković 2010).
} 
paraphrased as 'about linguistics'. In the topic-in-situ interpretation, the topic provides a frame for the entire sentence, paraphrasable along the lines of 'in terms of linguistics' or 'speaking of linguistics'.

(32) Extraction out of object

a. Tôi đã tìm được hai cuốn sách về ngôn ngữ học của Cao Xuân Hạo. I ANT seek obtain two CLS book about linguistics of Cao Xuan Hao 'I have found the two books about linguistics by Cao Xuan Hao.'

b. Về ngôn ngữ học thì tôi đã tìm được hai cuốn sách của Cao Xuân Hạo. about linguistics TOP I ANT seek obtain two CLS book of Cao Xuan Hao 'About linguistics, I have found two books by Cao Xuan Hao.' [raised topic] 'In terms of linguistics, I have found the two books by Cao Xuan Hao.' [topic-in-situ]

(33) Extraction out of subject

a. Hai cuốn sách về ngôn ngữ học của Cao Xuân Hạo chắc chắn sẽ gây two CLS book about linguistics of Cao Xuan Hao surely FUT cause ra tranh cãi.

out debate

'The two books about linguistics by Cao Xuan Hao will surely cause debate.'

b. Về ngôn ngữ học thì hai cuốn sách của Cao Xuân Hạo chắc chắn sẽ about linguistics TOP two CLS book of Cao Xuan Hao surely FUT gây ra tranh cãi.

cause out debate

*'About linguistics, the two books by Cao Xuan Hao will surely cause debate.' [*raised topic]

'In terms of linguistics, the two books by $\mathrm{CXH}$ will surely cause debate.' [topic-in-situ]

(Trinh 2004: 3)

Importantly, the topicalization facts are more symmetrical in a typical NP language like Chinese. As seen in (34) and (35), Chinese disallows the raised topic reading both in cases of extraction out of the subject and out of the object (Dong-yi Lin, p.c.).

(34) Extraction out of object

a. Wo zhao-dao liang ben Cao Xuan Hao xie de guanyu yuyianxue de shu I find-ASP two CLS Cao Xuan Hao write DE about linguistics DE book 'I have found two books about linguistics by Cao Xuan Hao'.

b. Guanyu yuyianxue wo zhao-dao liang ben Cao Xuan Hao xie de shu about linguistics I find-ASP two CLS Cao Xuan Hao write DE book *'About linguistics, I have found two books by Cao Xuan Hao.' [*raised topic] 'In terms of linguistics, I have found two books by Cao Xuan Hao.' [topic-in-situ]

(35) Extraction out of subject

a. Cao Xuan Hao xie de guanyu yuyianxue de liang ben shu yiding hui Cao Xuan Hao write DE about linguistics DE two CLS book surely will 
yinqi zhengyi

cause debate

'The two books about linguistics by Cao Xuan Hao will surely cause debate.'

b. Guanyu yuyianxue Cao Xuan Hao xie de liang ben shu yiding hui about linguistics Cao Xuan Hao write DE two CLS book surely will yinqi zhengyi

cause debate

*'About linguistics, the two books by Cao Xuan Hao will surely cause debate.' [*raised topic]

'In terms of linguistics, the two books by Cao Xuan Hao will surely cause debate.' [topic-in-situ]

In other words, Chinese is 'symmetric' whereas Vietnamese is 'asymmetric' when it comes to these extraction data.

Overall this means that Vietnamese patterns more with DP languages with regard to this property, and once again the DP-like nature of Vietnamese seems to be related to its topicprominent nature. Note that the raised topic in the Vietnamese examples above still conform to Paul and Whitman's (2015) definition of topic prominence: even though an XP has moved to Spec-TopP, Top ${ }^{0}$ is still filled by the base-generated topic particle thi.

\subsection{Interim summary}

Vietnamese exhibits both NP and DP properties. Vietnamese patterns with NP languages when it comes to its lack of a genuine definite determiner, the presence of radical pro-drop, and its lack of number morphology, but it patterns with DP languages when it comes to the presence of TP, subject expletives, and subject-object extraction asymmetries. The fact that Vietnamese does not display LBE is compatible with either NP or DP status. At least for Vietnamese, we have observed that for many of the clausal properties there is a relation to the topic-prominent nature of this language. Overall, the mixed status of Vietnamese suggests that the difference between article and article-less languages might not be as straightforward or clearcut as Bošković claims.

\section{Further properties}

In this section we look at properties that have to do with quantificational elements: negation, focus, and $w h$-items.

\subsection{Negative raising}

According to Bošković (2010: 5), languages without articles disallow negative raising and languages with articles allow it. Here Bošković restricts himself to negative raising from finite clauses, licensing strict clause-mate negative polarity items such as 'at least'. In this case, negative raising is not allowed in Vietnamese (37d).

(36) a. *John has visited her in at least 2 years.

b. John hasn't visited her in at least 2 years.

c. John believes that Mary hasn't visited him in at least 2 years. 
d. John doesn't believe that Mary has visited him in at least 2 years.

(Bošković 2010:4)

(37) a. *John đã thăm cô ây ít nhất 2 năm rồi John ANT visit 3SG least 2 year already

Intended: 'John has visited her in at least 2 years.'

b. John đã không thăm cô ấy ít nhất 2 năm rồi John ANT NEG visit $3 \mathrm{SG}$ least 2 year already

'John hasn't visited her in at least 2 years.'

c. John tin là Mary đã không thăm anh ấy ít nhất 2 năm rồi

John believe COMP Mary ANT NEG visit $3 \mathrm{SG}$ least 2 year already

'John believes that Mary hasn't visited him in at least 2 years.'

d. *John không tin là Mary đã thăm anh ấy ít nhất 2 năm rồi

John NEG believe COMP Mary ANT visit 3SG least 2 year already

Intended: 'John doesn't believe that Mary has visited him in at least 2 years.'

This means that Vietnamese patterns with NP languages, and it also tells us that there is no raising/movement of negation in this language.

\subsection{Focus adjacency}

Another of Bošković's proposed generalizations is that "elements undergoing focus movement are subject to a verb adjacency requirement only in DP languages" (Bošković 2010: 11). That is, in many DP languages the focused element has to move to a position adjacent to the verb, as shown in (38) for the DP language Bulgarian.

(38) Bulgarian (Bošković 2010:11)

a. *Kartinata Ivan podari na Maria painting.the $\mathrm{FOC}_{\mathrm{F}}$ Ivan give.as.present to Maria 'Ivan gave Maria the painting as a present.'

b. Kartinata podari Ivan na Maria painting.the $\mathrm{FOC}_{\mathrm{C}}$ give.as.present Ivan to Maria 'Ivan gave Maria the painting as a present.'

There is no such adjacency restriction when it comes to focalization in Vietnamese. Vietnamese usually uses the focus-in-situ strategy, as demonstrated in (39). ${ }^{22}$

(39) Ivan tặng Maria cả một bức tranh Ivan give.as.present Maria even one CLS picture 'Ivan gave Maria (even) one painting as a present.'

This property does not necessarily put Vietnamese in the NP group since DP languages do not necessarily display focus-verb adjacency (but when a language does display this

\footnotetext{
${ }^{22}$ Focus-in-situ can be directly associated with the fact that Vietnamese is a wh-in-situ language (Tran $2009, \mathrm{H}$. Nguyen 2012).
} 
requirement, the language should be a DP language according to Bošković). Thus, strictly speaking, the absence of focus-verb adjacency in Vietnamese says nothing about its NP/DP status. What we do know, however, is that focus movement is unnecessary in Vietnamese.

\subsection{Focus morphology}

Bošković (2010: 8) also claims that "negative constituents must be marked for focus in NP languages." For an NP language like Mandarin Chinese, Cheng (2013) claims that negative constituents always come with focus elements. When the polarity element stays in its base position (40a), there is no polarity reading (only the interrogative reading). The negative/polarity element shei 'who' must be fronted and co-occur with the focus element dou 'all' (40b) in order to get the polarity reading.

$$
\begin{aligned}
& \text { a. Zhangsan bu renshi shei } \\
& \text { Zhangsan not know who } \\
& \text { 'Who doesn't Zhangsan know?' } \\
& \text { \#'Zhangsan does not know anyone. }{ }^{23}
\end{aligned}
$$

$$
\begin{aligned}
& \text { b. Zhangsan shei dou bu renshi } \\
& \text { Zhangsan who all not know } \\
& \text { 'Zhangsan does not know anyone.' }
\end{aligned}
$$

(Cheng 2013:26)

However, Cheng's analysis cannot be extended to Vietnamese. Whereas in Chinese it seems that what is needed to derive the NPI usage of shei is a focus marker like dou, in Vietnamese this is not the case. The Vietnamese counterparts of (40) are in (41).
a. Zhangsan không biết ai
Zhangsan NEG know who
'Zhangsan does not know anyone.'
\#'Who doesn't Zhangsan know?'
b. Zhangsan ai cũng không biết
Zhangsan who also NEG know
'Zhangsan does not know anyone.'

As can be seen in (41a), the NPI usage of $a i$ is derived even in the absence of the focal element cunng. In fact, in sharp contrast with Chinese (40a), this is the only possible reading of (41a). ${ }^{24}$

The question now is what the role of the focal element cung in (41b) is, if it is not related to negation. The answer will become clearer if we take out the negation marker in (41b).

\footnotetext{
23 'Who doesn't Zhangsan know?' is rendered in Vietnamese as:

(iii) Zhangsan không biết ai thế?

Zhangsan NEG know who PRT

'Who doesn't Zhangsan know?'

See Tran (2009) for an analysis of the question particle thế. See also Duffield (in press) for an alternative.

${ }^{24}$ The contrast between (40a) and (41a) also points out an interesting difference between Vietnamese and

Chinese with respect to intervention effects. (40) seems to suggest that there might be no intervention effect in

Chinese (the wh-element shei moves across negation) (Cheng 1991). However, (41) indicates that Vietnamese might show an intervention effect: ai cannot be interpreted as [+wh] here because of the intervention of the negation marker không (see also H. Nguyen 2012 for further discussion). Cf. also example (iii) above.
} 
As argued by C. Nguyen (2013), (42) and (41b) are cases of a universal quantification construction involving a preposed $w h$-phrase and the preverbal focal element cũng, independent of the presence or absence of negation markers.

Two comments are in order here. First, the precise nature of this construction is beyond the scope of the paper, but suffice it to say that negation does not need to be marked for focus in Vietnamese. This is a DP property according to Bošković. Second, the wh-word ai moves out of its post-verbal base-generated position in (41b) and (42), suggesting the possibility of whmovement in Vietnamese. However, the nature of this movement in Vietnamese is different from classical wh-movement. In classical wh-constructions, the feature [+wh] on $a i$ is checked in-situ in Vietnamese, while the movement of ai in cases like (42) is driven by features responsible for universal quantification.

\section{Discussion}

In this paper we have taken seriously Bošković's (2005, 2008, 2009, 2010) hypothesis that there is an important typological difference between languages with and languages without definite determiners. We have shown that Vietnamese falls on the border between NP and DP.

(43) Dual status of Vietnamese with respect to NP/DP parameter

\begin{tabular}{|l|l|l|}
\hline Properties & NP & DP \\
\hline a. Definite determiner & $\checkmark$ & \\
\hline b. Left branch extraction & $(\checkmark)$ & $(\checkmark)$ \\
\hline c. Radical prodrop & $\checkmark$ & \\
\hline d. Obligatory number morphology & $\checkmark$ & \\
\hline e. TP & & $\checkmark$ \\
\hline f. Subject expletives & & $\checkmark$ \\
\hline g. Subject-object asymmetry & & $\checkmark$ \\
\hline h. Negative raising & $\checkmark$ & \\
\hline i. Focus-verb adjacency & $(\checkmark)$ & $(\checkmark)$ \\
\hline j. Focus morphology on negative constituents & & $\checkmark$ \\
\hline
\end{tabular}

The in-between status of Vietnamese suggests that the NP/DP macro-parameter and its host of properties in (43) needs to be reevaluated. ${ }^{25}$

We would like to suggest a reassessment along the following lines. First, note that properties (a-d) in (43) all have to do with the structure of the noun phrase. Moreover, these properties are not 'mixed' with regard to NP/DP status. That is, they are all consistent with Vietnamese as an NP language. Second, note that properties (e-g) in (43) have more to do with clausal structure than nominal structure. Moreover, these properties point to DP status for

\footnotetext{
${ }^{25}$ In a different study, we argue that Vietnamese differs from Chinese with respect to definiteness expression. The main contrast between Chinese and Vietnamese is that in Chinese, there is no need to project D (for definiteness) because other existing elements in the nominal phrase can do the job (numerals and classifiers; see Cheng and Sybesma 1999, 2005), whereas in Vietnamese such other things still are not sufficient (Phan 2014). This suggests that even in classifier languages there is a need for DP.
} 
Vietnamese. Finally, properties (h-j) have to do with quantificational elements like negation, focus, and wh-elements (Starke 2001). These are mixed with regard to NP/DP status, but they share the fact that they do not, on the whole, undergo movement: in section 3 we saw that negation does not raise, nor do focalized elements move; at various points in the paper it was also pointed out that Vietnamese is a wh-in-situ language. On the other hand, nonquantificational movement like topicalization is perfectly allowed in Vietnamese.

We propose, then, that the table should be redrawn with the boundaries shown in (44).

(44) Three independent parameters

\begin{tabular}{|c|c|c|c|}
\hline Properties & NP & DP & Parameter \\
\hline a. Definite determiner & 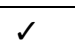 & & \multirow{4}{*}{ (i) } \\
\hline b. Left branch extraction & $(\checkmark)$ & $(\checkmark)$ & \\
\hline c. Radical prodrop & $\checkmark$ & & \\
\hline d. Obligatory number morphology & 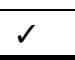 & & \\
\hline e. TP & & $\checkmark$ & \multirow{3}{*}{ (ii) } \\
\hline f. Subject expletives & & $\checkmark$ & \\
\hline g. Subject-object asymmetry & & 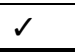 & \\
\hline h. Negative raising & $\checkmark$ & & \multirow{3}{*}{ (iii) } \\
\hline i. Focus-verb adjacency & $(\checkmark)$ & $(\checkmark)$ & \\
\hline j. Focus morphology on negative constituents & & $\checkmark$ & \\
\hline
\end{tabular}

As far as the nominal properties are concerned (44i), Vietnamese is an NP language. As far as the clausal properties are concerned (44ii), Vietnamese is a DP language. And as far as the quantificational (negation, focus, wh-elements; Starke 2001) properties are concerned (44iii), there is no movement. Rather than assigning Vietnamese a mixed NP/DP status, however, it seems more likely that there are independent parameters at work.

In order to explain the behavior of Vietnamese with respect to the three parameters in (44), we need to claim the following: Vietnamese (i) lacks a DP (in Bošković's terms), (ii) has a $\mathrm{TP}$, and (iii) keeps its quantificational elements in situ. Moreover, Vietnamese is a topicprominent language. From these four claims the properties in (44) fall out.

Though we do not necessarily accept the finer details of Bošković's formal analysis of NP languages as lacking a DP projection, Vietnamese is consistent with Bošković's classification of NP languages as far as the nominal properties of parameter (i) are concerned. According to Bošković's analysis, then, Vietnamese would lack a DP, which accounts for (a) the lack of a definite determiner, (c) radical pro-drop, and (d) non-obligatory number morphology. Next, the fact that Vietnamese has a TP (property (e)) is closely linked to (f) its subject-domain expletive nó and ( $\mathrm{g}$ ) certain subject-object asymmetries. The fact that Vietnamese is a quantificational-in-situ language makes sense of the way negation (properties $(\mathrm{h})$ and $(\mathrm{j})$ ), focus (properties (i) and (j)), and wh-items (wh-in-situ status and the lack of complement extraction in connection with property (b)) pattern in this language. Finally, the fact that Vietnamese is a topic-prominent language, with its base-generated topic particle thi (see Paul and Whitman 2015), accounts for its contrastive topic construction (which resembles LBE), the licensing of radical pro-drop, and the raised topic construction discussed in connection with property $(\mathrm{g}){ }^{26}$

\footnotetext{
${ }^{26}$ It can be noted that many NP languages fall into the category of so-called non-configurational languages (Bošković 2010: 34-35), a category that also overlaps with discourse-configurational languages (see Kiss 1994
} 


\section{Conclusion}

In sum, we have shown that Bošković's NP/DP parameter breaks down into at least three separate parameters. In many languages, these three parameters line up in a consistent manner and conspire to give the impression that there is a single macro-parameter at work. However, due to its mixed status, Vietnamese reveals that there are in fact three smaller parameters (nominal, clausal, and quantificational) at work, and that these are independently fixed (as [-DP], [+TP], and [-movement], respectively). Moreover, Vietnamese can in general be classified as a topic-prominent language, a classification which requires more research but which plays an important role in determining the behavior of Vietnamese with regard to many of the syntactic properties discussed above.

\section{References}

Abels, Klaus. 2003. Successive cyclicity, anti-locality, and adposition stranding. Doctoral dissertation, University of Connecticut.

Bošković, Željko. 2005. On the locality of left branch extraction and the structure of NP. Studia Linguistica 59:1-45.

Bošković, Željko. 2008. What will you have, DP or NP? Proceedings of NELS 37:101-114.

Bošković, Željko. 2009. More on the no-DP analysis of article-less languages. Studia Linguistica 2:187-204.

Bošković, Željko. 2010. On NPs and clauses. Ms., University of Connecticut.

Bui, Manh Hung. 2000. Về một số đặc trưng ngữ nghĩa - ngữ pháp của nhũ̃ng và các (Some sematico-syntactic characteristics of những and các). Ngôn ngũu 3: 16-26.

Cao, Xuan Hao. 2004. Tiếng Việt So Thảo Ngũu Pháp Chú Năng (A functional grammar of Vietnamese). Hà Nội: Giáo dục.

Carrilho, Ernestina. 2007. Beyond subject doubling: Expletive constructions in European Portuguese dialects. Amsterdam: Meertens Institute. Available online at http://www.meertens.knaw.nl/projecten/edisyn/Online_proceedings/Paper_Carrilho.pdf

Cheng, Hsu-Te. 2013. Argument ellipsis, classifier phrases, and the DP parameter. Doctoral dissertation, University of Connecticut.

Cheng, Lisa. 1991. On the typology of wh-questions. Doctoral dissertation, MIT.

Cheng, Lisa and Rint Sybesma. 1999. Bare and not-so-bare nouns and the structure of NP. Linguistic Inquiry 30(4):509-542.

Cheng, Lisa and Rint Sybesma. 2005. Classifiers in four varieties of Chinese. In The Oxford handbook of comparative syntax, ed. Guglielmo Cinque and Richard Kayne, 259-292. New York: Oxford University Press.

Chomsky, Noam. 2000. Minimalist inquiries. In Step by step: Essays on Minimalist syntax in honor of Howard Lasnik, ed. Roger Martin, David Michaels, and Juan Uriagereka, 89155. Cambridge, MA: MIT Press.

Cresti, Diana. 1995. Indefinite topics. Doctoral dissertation, MIT.

Dao, Huy Linh. 2012. Intransitivité scindée, passif et sujet impersonnel en vietnamien. In Actes du 3le Colloque International sur le Lexique et la Grammaire, ed. Jan Radimský, 49-55. Nové Hrady: Université de Bohême du Sud à České Budějovice.

Duffield, Nigel. 2007. Aspects of Vietnamese clause structure: Separating tense from assertion. Linguistics 45(4):765-814.

and Miyagawa 2010), defined as languages with designated positions for both topic and focus. Vietnamese, however, due to its focus-in-situ status, is more accurately defined as a topic-prominent language, not a discourse-configurational or non-configurational language. 
Duffield, Nigel. 2013. Head-first: On the head-initiality of Vietnamese clauses. In Linguistics of Vietnamese: An international survey, ed. Daniel Hole and Elisabeth Löbel, 127-155. Berlin: Mouton de Gruyter.

Duffield, Nigel. In press. On what projects: Anti-projection and multifunctionality in Vietnamese. Paper submitted to JEAL.

Duffield, Nigel. In prep. Particles and Projections in Vietnamese Syntax. Ms., Konan University.

Emeneau, Murray B. 1951. Studies in Vietnamese grammar. Berkeley: University of California Press.

Enç, Mürvet. 1991. The semantics of specificity. Linguistic Inquiry 22(1):1-25.

Farkas, Donka F. 2002. Specificity distinctions. Journal of Semantics 19: 213-243.

Gallego, Ángel J. and Juan Uriagereka. 2007. Sub-extraction from subjects: A phase theory account. In Romance linguistics 2006, ed. José Camacho, Nydia Flores-Ferrán, Liliana Sánchez, Viviane Déprez, and María José Cabrera, 149-162. Amsterdam: John Benjamins.

Greco, Ciro, Trang Phan, and Liliane Haegeman. In prep. There is nó expletive in Vietnamese after all. Ms., Ghent University.

Himmelmann, Nikolaus. 2001. Chapter 62: Articles. In Language typology: An international handbook, Vol. 1, 831-841. Berlin: Walter de Gruyter.

Holmberg, Anders. 2010. Null subject parameters. In Parametric variation: Null subjects in Minimalist theory, ed. Theresa Biberauer, Anders Holmberg, Ian Roberts, and Michelle Sheehan, 88-124. Cambridge: Cambridge University Press.

Holmberg, Anders and Urpo Nikanne. 2002. Expletives, subjects, and topics in Finnish. In Subjects, expletives, and the EPP, ed. Peter Svenonius, 71-105. Oxford: Oxford University Press.

Kirby, James P. 2006. Vietnamese and the structure of NP. Ms., Edinburgh University.

Kiss, Katalin É. 1994. Discourse Configurational Languages. Oxford: Oxford University Press.

Lander, Eric T. and Liliane Haegeman. 2014. Old Norse as an NP Language: With Observations on the Common Norse and Northwest Germanic Runic Inscriptions. Transactions of the Philological Society 112(3):279-318.

Li, Jiang. 2012. Nominal arguments and language variation. Doctoral dissertation, Harvard University.

Miyagawa, Shigeru. 2010. Why agree? Why move? Unifying agreement-based and discourseconfigurational languages. Cambridge, MA: MIT Press.

Nguyen, Chieu. 2013. Fusion and scattering in particle collisions: When universal quantification and contrastive focus interact with themselves and each other in Vietnamese. In Proceedings of GLOW in Asia IX 2012, ed. Nobu Goto, Koichi Otaki, Atsushi Sato, and Kensuke Takita, 213-228. Mie University, Japan.

Nguyen, Hanh. 2012. Wh-questions in Vietnamese. Master's thesis, University of Nantes.

Nguyen, Hung Tuong. 2004. The structure of the Vietnamese noun phrase. Doctoral dissertation, Boston University.

Nguyen, Van Hiep and Nguyen Hoang Thuy. 2011. Về chủ ngữ giả trong tiếng Việt (Dummy subjects in Vietnamese). Paper presented at the $11^{\mathrm{th}}$ International Conference on Linguistics Training and Research in Vietnam, Hà Nội.

Paul, Waltraud and John Whitman. 2015. Topic prominence. To appear in The Blackwell companion to syntax, $2^{\text {nd }}$ edition, ed. Martin Everaert and Henk van Riemsdijk.

Available at Lingbuzz, lingbuzz/002399.

Phan, Trang. 2013. Syntax of Vietnamese aspect. Doctoral dissertation, University of Sheffield. 
Phan, Trang. 2014. Definiteness in Vietnamese in comparison to Chinese. Paper presented at CamCos 3, Cambridge, UK.

Phan, Trang and Eric T. Lander. In prep. Plurality in classifier languages: A Vietnamese perspective. Ms., Ghent University.

Portner, Paul. 2002. Topicality and (non)-specificity in Mandarin. Journal of Semantics 19: 275-287.

Roberts, Ian and Anders Holmberg. 2010. Introduction. In In Parametric variation: Null subjects in Minimalist theory, ed. Theresa Biberauer, Anders Holmberg, Ian Roberts, and Michelle Sheehan, 1-57. Cambridge: Cambridge University Press.

Starke, Michal. 2001. Move dissolves into merge: A theory of locality. Doctoral dissertation, University of Geneva.

Thompson, Laurence C. 1965. A Vietnamese Grammar. Seattle: University of Washington Press.

Tran, Thuan. 2009. Wh-quantification in Vietnamese. Doctoral dissertation, University of Delaware.

Trinh, Tue. 2004. Một cách nhìn tiếng Việt quái gở? (An "awkward" approach to Vietnamese?). Talawas. Available online at http://tusach.thuvienkhoahoc.com/wiki.

Trinh, Tue. 2005. Aspects of clause structure in Vietnamese. Master's thesis, Humboldt University.

Tsai, Cheng-Yu Edwin. 2009. Wh-dependency in Vietnamese and the syntax of wh-in-situ. Master's thesis, National Tsing Hua University. 